\title{
Muscle Fibre Types and Connective Tissue Morphometry in Frontal Muscle of Norfolk Rabbits (Oryctolagus cuniculus)
}

\author{
Morfometría de los Tipos de Fibra Muscular y del Tejido Conectivo \\ en Músculo Frontal de Conejos Norfolk (Oryctolagus cuniculus)
}

André Hebling; José Eduardo Scabora \& Marcelo Augusto Marretto Esquisatto

HEbling, A.; SCABORA, J. E. \& ESQUiSATTO, M. M. A. Muscle fibre types and connective tissue morphometry in frontal muscle of Norfolk rabbits (Oryctolagus cuniculus). Int. J. Morphol., 27(1):187-191, 2009.

SUMMARY: The frontal muscle is formed by a complex of contractile elements which compose the set of facial muscles responsible for the expression of emotions. In view of its functional characteristics the frontal muscle consists of a mixture of high (type I) and low oxidative (type II) muscle fibres. The objective of the present study was to determine the area, diameter, and relative volume occupied by each fibre type in frontal muscles of Norfolk rabbits using nicotinamide adenine dinucleotide tetrazolium reductase (NADHTR) histochemistry combined with morphometry. In addition, the connective tissue area (endomysium) and the number of blood vessels per fibre were evaluated. Female rabbits ranging in age from 6 to 8 months and weighing 2.8 to $3.1 \mathrm{~kg}$ were used. Four quadrants of samples from 12 animals were analysed. Type IIB fibres occupied the largest area compared to the other fibre types. The fibre diameter and relative volume were similar among the different fibre types identified by NADH-TR staining. No significant difference in the number of vessels per fibre was observed between the different fibre types. The endomysial area occupied the smallest area among the parameters analyzed. These findings demonstrated the intense activity of this muscle in the facial architecture of the animal. However, the low oxidative type II fibres predomination indicates more prone to muscle fatigue. The present findings may contribute to the study of myopathies involving this muscle.

KEY WORDS: Morphometry; Frontal muscle; Fibre type; Connective tissue.

\section{INTRODUCTION}

Our understanding of motor control of the human facial muscles is mainly derived from the results of experimental animal studies. However, the morphofunctional relationships of facial movements related to mastication and facial mimic and the muscle fibre population involved are still poorly understood.

Anatomically, the frontal muscle controls facial mimic, particularly in humans, and forms together with the occipital belly, which are connected by the galea aponeurotica, the occipitofrontalis muscle. The two bellies act independently despite the galea aponeurotica. The frontal belly raises the eyebrows and pulls the galea aponeurotica, forming transverse wrinkles on the forehead. The occipital belly is responsible for drawing back the galea aponeurotica and participates in facial expressions during smiling and in movements of the auricle (Berkovitz et al., 1992).
Histoenzymology of skeletal muscles has been successfully applied to the differentiation of functionally distinct fibre groups. This differentiation is based on the concentration of oxireductases, especially diaphorase oxireductases such as nicotinamide adenine dinucleotide tetrazolium reductase (NADH-TR), in muscle tissues (Dubowitz \& Brooke, 1973). Application of the NADH-TR method results in different oxidative reactions that permit the classification of muscle fibres into strongly oxidative (type I) and weakly oxidative (type II) fibres (Dubowitz et al., 1985).

In view of the diseases affecting the frontal muscle and the lack of morphometric studies regarding the muscle fibre types and connective tissue sheaths comprising its belly, the objective of the present study was to quantitatively determine the area, diameter and relative volume of each 
fibre type (I, IIA and IIB), number of blood vessels per fibre and connective tissue (endomysium) area in these muscles obtained from a population of rabbits held in captivity.

\section{MATERIAL AND METHOD}

Animals. Ten adult female Norfolk rabbits ranging in age from 6 to 8 months and weighing 2.8 to $3.1 \mathrm{~kg}$, obtained from the Animal House of the Faculty of Medicine of Botucatu, Universidade Estadual Paulista (UNESP), were studied. The animals were maintained in captivity and fed adequate ration and water ad libitum. All animal procedures were carried out in accordance with the ethical guidelines of the Brazilian College of Animal Experimentation.

Tissue samples and histochemistry. For removal of the frontal muscle, the animals were anesthetized with $3 \%$ Hypnol at the dose of $30 \mathrm{mg} / \mathrm{kg}$ body weight and then killed by inhalation of sulfuric ether. A $15-\mathrm{mm}^{2}$ fragment was removed from the left belly of each animal, placed in a Petri dish, identified and immediately submitted to appropriate processing. The muscle specimens were frozen in n-hexane and cooled to $-70^{\circ} \mathrm{C}$ with liquid nitrogen. Next, the specimens were transferred to a Leica CM 1800 cryostat chamber at $-20^{\circ} \mathrm{C}$, where they remained for 40 min for thermal adaptation. The specimens were fixed in a metal support (Tissue-Tek-OCT) and cut into $8-\mu \mathrm{m}$ thick sections with a microtome. The sections were incubated in an oven at $37^{\circ} \mathrm{C}$ for $10 \mathrm{~min}$. Next, the sections were submitted to histochemistry for the identification of NADH-TR according to the method of Dubowitz et al. According to this author, the technique permits the differentiation of three distinct fibre types (I, IIA and IIB). The sections were documented using a Zeiss MC 80 DX light photomicroscope at 10X magnification. The images of NADH-TR-stained sections were analyzed at $180 \mathrm{X}$ magnification and divided into four equal quadrants.

Morphometry of muscle fibres and connective tissue sheaths. On the basis of the quadrants delimited in the sections obtained from the muscle belly of each specimen, the area, diameter and relative volume of each fibre type, as well as the connective tissue area (endomysium) in relation to the total area sampled for each animal, were determined with the Sigma Scan Pro 6.0® program. The relative volume is reported as the ratio between the sum of areas and the absolute number of each fibre type in all samples. In addition to these parameters, the mean number of capillaries per quadrant and the ratio were quantified for each fibre type.
The results are reported as mean and standard deviation for the samples obtained from the 10 animals analysed. The data are summarized in Table I and were compared by the Tukey test, with the level of significance set at $5 \%$.

\section{RESULTS}

In figure 1 illustrates two specimens stained by the NADH-TR method, demonstrating the distribution of the different muscle fibre types and the differentiation between the endomysium and blood capillaries.

The morphometric parameters of the samples studied are summarized in Table I. A significant difference between fibre types was only observed for the area occupied, with the largest area being occupied by type IIB fibres. The fibre diameter and relative volume were similar among the different fibre types identified by NADH-TR staining. No significant difference in the number of vessels per fibre was observed between fibre types. The endomysium occupied the smallest area compared to the other parameters analyzed.

\section{DISCUSSION}

The distribution of muscle fibres according to oxidative capacity is not homogenous in the frontal muscle of rabbits. This fact has also been reported in a large number of investigations analysing fibre types in mammals (Augusto et al., 2004) and has been well documented for cranial muscles by Bredman et al. (1990).

In the present study, NADH-TR oxidative staining was used for the differentiation of three muscle fibre types. This method is commonly used in the literature and permits the differentiation of fibres according to their oxidative capacity (Dubowitz \& Brooke; Dubowitz et al.). Our results indicate a predominance of type IIB fibres compared to the other fibre types in the total tissue mass, with no differences in mean diameter being observed between fibre populations. This fact agrees with previous findings from our group regarding fibre counts (Hebling et al., 2006). In the case of muscles located in the cranium, the morphofunctional adaptation of the muscle to its main activity seems to be an initial increase in the number of fibres and not in their diameter.

The work capacity of a muscle is closely related to the fibre population and quantity of connective tissues 

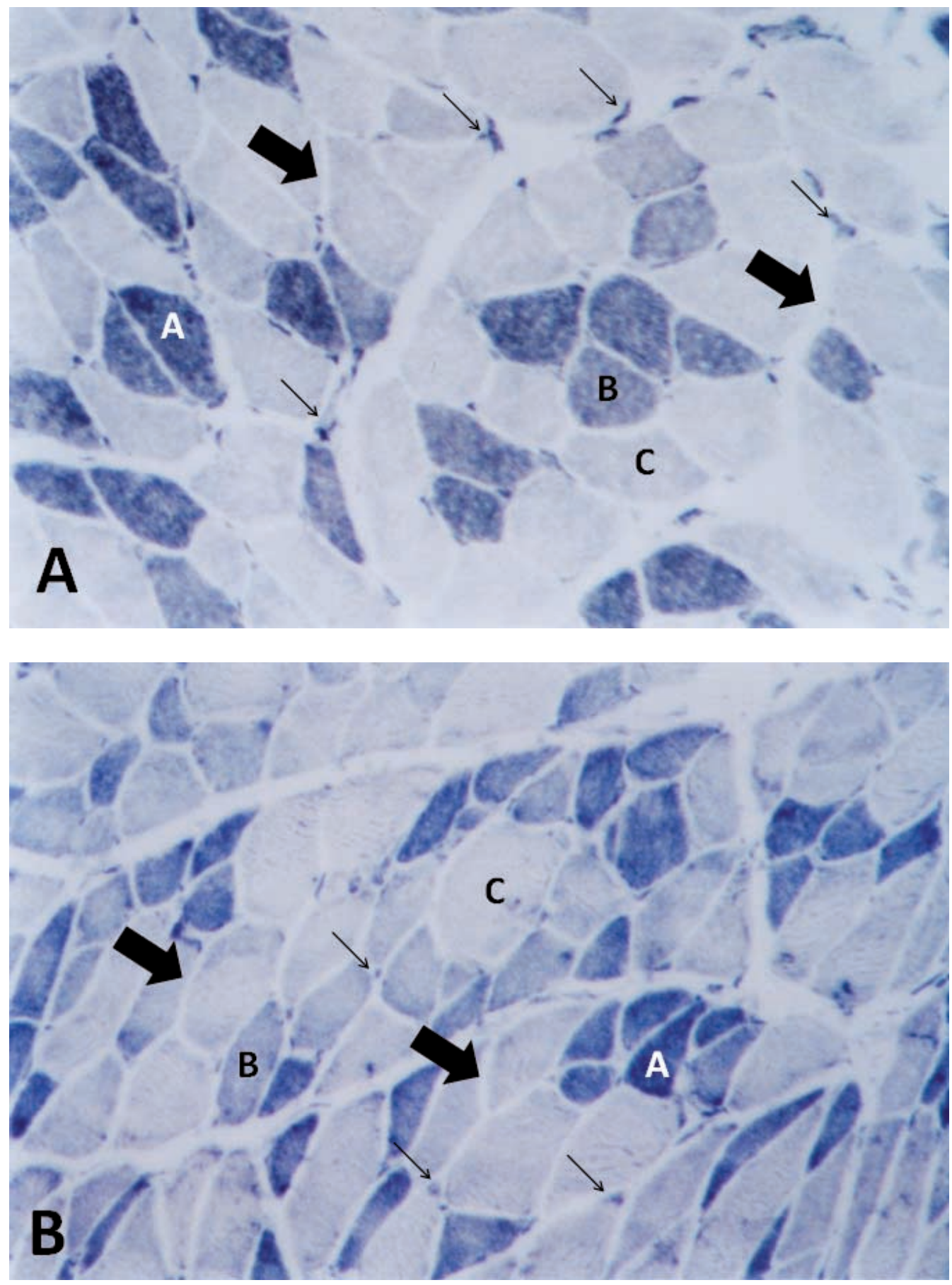

Fig. 1. Photomicrographs obtained for specimens 6 (A) and 7 (B) after NADH-TR histochemistry. Note the differences in fibre type distribution between the animals studied. A, type I; B, type IIA; C, type IIB. The arrow points to a blood vessel and the arrowhead indicates the endomysium. 180X.

Table I. Morphometric parameters obtained for the different fibre types and endomysium of the frontal muscle of English Norfolk rabbits (Oryctolagus cuniculus). The results were compared by the Tukey test (5\% level of significance). *: significant difference.

\begin{tabular}{lcccc}
\hline Quantitative parameter & Type I muscle fibre & Type IIA muscle fibre & Type IIB muscle fibre & Endomysium \\
\hline Diameter $(\boldsymbol{\mu m})$ & $51.0 \pm 5.2$ & $46.7 \pm 7.1$ & $48.8 \pm 4.7$ & - \\
Area $\left(\boldsymbol{\mu m}^{2}\right)(*)$ & $1524.6 \pm 432.5$ & $787.1 \pm 223.2$ & $2204.6 \pm 625.4$ & $479.7 \pm 187.8$ \\
Relative volume $\left(\boldsymbol{\Sigma} \boldsymbol{u m}^{2} / \mathbf{N}\right)$ & $4.47 \pm 1.26$ & $3.57 \pm 2.38$ & $4.59 \pm 1.38$ & - \\
Number of capillaries per fibre & $2.2 \pm 0.6$ & $2.1 \pm 0.7$ & $1.9 \pm 0.6$ & - \\
\hline
\end{tabular}


between fibres (Richmond et al., 2001). The predominance of type II fibres, especially subtype B, indicates that the frontal muscle of rabbits presents a weak oxidative metabolism and is prone to fatigue during prolonged work. Similar findings have been reported for the masseter (Bredman et al.) and suprahyoid muscles (Bonington et al., 1987, 1988; Brownlow et al., 1989).

The similar functional behavior of facial and neurocranial muscles is in contrast to the great morphofunctional diversity observed for trunk and limb muscles. Muscle heterogeneity is closely related to the fibre population which, in turn, responds to different functional requirements (Latorre et al., 1993).

Another aspect related to the tissue's response to work demand observed in facial and limb muscles is compartmentalization of the fibre population (Braund \& Lincoln, 1981). This regionalization shows a close association with blood flow (Weijs \& Dantuma, 1981; Weijs et al., 1989). The present findings indicate the absence of fibre regionalization in the frontal muscle of rabbits and that blood flow to the fibres seems to be constant in view of the observation of a similar number of vessels per fibre.

Finally, the integrative role of connective tissue associated with muscular contractile elements should be emphasized. The endomysium connects muscle cells, preserving the physical integrity of the muscle during contraction, in addition to functioning as a conduction vehicle for vascular and nervous elements (Di Dio, 2003). Despite the small number of reports in the literature analysing the volume occupied by the endomysium in normal muscles obtained from different anatomical sites and different mammalian species, it is known that the deposition of fibrous matrix elements increases in immobilized muscle (Jarvinen et al., 2002) or muscle submitted to experimental denervation (Fernandes et al., 2005). In view of the findings obtained under abnormal conditions, the content of connective tissue found in the frontal muscle of rabbits should represent normality for this structure.

In conclusion, our study contributes to the quantitative analysis of the fibre population in the frontal muscle of Norfolk rabbits and provides morphological evidence for the predominantly low oxidative activity of this muscle.

\section{ACKNOWLEDGEMENTS}

This study was supported by CNPq/MCT, Brazil, and PROPESq/UNIARARAS.

HEBLING, A.; SCABORA, J. E. \& ESQUISATTO, M. M. A. Morfometría de los tipos de fibra muscular y del tejido conectivo en músculo frontal de conejos Norfolk (Oryctolagus cuniculus). Int. J. Morphol., 27(1):187-191, 2009.

RESUMEN: El músculo frontal está formado por un complejo de elementos contráctiles que componen el conjunto de músculos faciales responsables de la expresión de emociones. A la vista de las características funcionales, el músculo frontal está constituido de una mezcla de fibras musculares de alto (tipo I) y bajo nivel de oxidación (tipo II). El objetivo del presente estudio fue determinar área, diámetro y volumen relativo ocupado por cada tipo de fibra en los músculos frontales de conejos Norfolk utilizando histoquímica para nicotinamide adenina dinucleotide tetrazolium reductasa (NADH-TR), combinado con su morfología. Además, fueron evaluados la zona de tejido conectivo (endomisio) y el número de vasos sanguíneos por fibras. Fueron utilizados conejos hembras, de edades comprendidas entre los 6 a 8 meses y con un peso de 2,8 a 3,1 kg. Se analizaron cuatro cuadrantes de las muestras de 12 animales. Las fibras tipo IIB ocuparon la mayor superficie, en comparación con los otros tipos de fibras. Los diámetros y volúmenes relativos de las fibras fueron similares entre los diferentes tipos identificados por NADH-TR. No se observaron diferencias significativas en el número de vasos por fibra, entre los diferentes tipos de fibras. El área ocupada por el endomisio fue la superficie más pequeña entre los parámetros analizados. Estos resultados demostraron la intensa actividad de este músculo en la arquitectura facial del animal. Sin embargo, el predominio de las fibras tipo II, de baja oxidación, indica más propensión a la fatiga muscular. El presente hallazgo pueden contribuir al estudio de las miopatías con la participación de este músculo.

PALABRAS CLAVE: Morfometría; Músculo frontal; Tipos de fibra; Tejido conectivo.

\section{REFERENCES}

Augusto, V.; Padovani, C. R. \& Campos, G. E. R. Skeletal muscle fiber types in C57BL6J mice. Braz. J. Morphol. Sci., 21:89-94, 2004.
Berkovitz, B. K. B.; Holland, G. R. \& Moxham, B. J. Color Atlas \& Textbook of Oral Anatomy. New York, Mosby, 1992. 
Bonington, A.; Mahon, M. \& Whitmore, I. A histological and histochemical study of the cricopharyngeus muscle in man. J. Anat., 156:27-37, 1988.

Bonington, A.; Whitmore, I. \& Mahon, M. A. A histological and histochemical study of the cricopharyngeus muscle in the guinea-pig. J. Anat., 153:151-61, 1987.

Braund, K. G. \& Lincoln, C. E. Histochemical differentiation of fiber types in neonatal canine skeletal muscle. Am. J. Vet. Res., 42:407-15, 1981.

Bredman, J. J.; Weijs, A.W.; Moorman, A. F. M. \& Brugman, P. Histochemical and functional fibre typing of the rabbit masseter muscle. J. Anat., 168:31-47, 1990.

Brownlow, H.; Whitmore, I. \& William, P. L. T. A quantitative study of the histochemical and morphometric characteristics of the human cricopharyngeus muscle. $J$. Anat., 166:67-75, 1989.

Di Dio, L. J. A. Tratado de Anatomia Aplicada. São Paulo, Atheneu, 2003.

Dubowitz, V. \& Brooke, M. H. Muscle biopsy: A modern approach. London, W.B. Saunders, 1973.

Dubowitz, V., C. A. S. \& Fitzsimons, R. B. Muscle Biopsy: A Practical Approach. $2^{\text {nd }}$ ed. London, Baillière Tindall, 1985.

Fernandes, K. C. B. G.; Polacow, M. L. O.; Guirro, R. R. J.; Campos, G. E. R.; Somazz, M. C.; Pinto, V. F.; Fuentes, C. B. \& Teodori, R. M. Análise morfométrica dos tecidos muscular e conjuntivo após desnervaçao e estimulação elétrica de baixa frequiência. Rev. Bras. Fisiot., 9:23541, 2005.

Hebling, A.; Esquisatto, M. A. M. \& Castro, H. A. L. Estudio histoquímico de la enzima NADH-TR em Musculo Frontal de Conejos Norfolk (Oryctolagus cuniculus). Int. J. Morphol., 24:151-4, 2006.

Jarvinen, T. A. H.; Jozsa, L.; Kannus, P.; Jarvinen, T. L. N. \& Jarvinen, M. Organization and distribution of intramuscular connective tissue in normal and immobilized skeletal muscles. J. Muscle Res. Cell Mot., 23:245-54, 2002.

Latorre, R.; Gil, F.; Vazquez, J. M.; Moreno, F.; Mascarello, F. \& Ramirez, G. Skeletal muscle fibre types in the dog. J. Anat., 182:329-37, 1993.
Richmond, F. J. R; Singh K. \& Corneil, B. D. Neck muscles in the rhesus monkey. I. Muscle morphometry and histochemistry. J. Neurophysiol., 86:1717-28, 2001.

Weijs, W. A. \& Dantuma, R. Functional anatomy of the masticatory apparatus in the rabbit. Netherlands J. Zool., 31:99-147, 1981.

Weijs, W. A.; Brugman, P. \& Grinbergen, C. A. Jaw movements and muscle activity during mastication in growing rabbits. Anat. Rec., 224:407-16, 1989.

Correspondence to:

Prof. André Hebling

Disciplina de Anatomia Humana

Centro Universitário Hermínio Ometto- UNIARARAS

Av. Dr. Maximiliano Baruto, 500

Jd. Universitário

Araras/SP - 13607-339

BRASIL

Tel/Fax : 055019 3543-1517

Email : andrehebling@uniararas.br

Received: 02-06-2008

Accepted: 22-10-2008 
